\title{
Notary Authority to Provide Legal Counseling Service Based On Notary Law and Notary Code in Banjarnegara
}

\author{
Bondan Zakaria Bushido1, Risky Eko Novi Artanto ${ }^{2}$ and Gunarto ${ }^{3}$
}

Abstract. The purpose of this study was to determine and analyze Notary authority in Providing Legal counseling in terms of Act No. 2 of 2014 on Amendment of Act No. 30 of 2004 concerning Notary and Notary Code. And to analyze Obstacles and Solutions for a Notary in Role Gives Legal counseling.

This study uses empirical juridical approach, the specification is descriptive analytical research, data sources used in the form of primary data obtained through interviews, secondary data with the literature study, qualitative analysis. The problem is analyzed using the theory of Authority and Accountability.

Based on the results of this study concluded that 1) Notary authority in providing Legal counseling to Its clients can be divided into two (2) Criteria, namely a) Legal counseling followed by Creation Deed and b) Legal counseling without being followed by Creation Deed. 2) The obstacles in conducting Legal counseling, namely a) Effect of Kinship properties, b) Effect of Position, c) Influence of Consumerism, d) Profession into Business Activity, e) Due to Weak Faith. Solutions to resolve impediments in doing Notaries Legal counseling Legal counseling is doing that is not followed by Creation Deed.

Keywords: Notary authority; Legal counseling.

\section{Introduction}

Indonesia is a State of Law, which is listed in Article 1 (3) of the Law of the Republic of Indonesia hereinafter written (UUDNRI 1945) "Indonesia is a State of Law" characteristic of the Rule of Law State Law. ${ }^{4}$ For the Rule of Law in need Authentic Deed under Article 1868 of the Civil Code. The Authentic Deed made before a public official. Public Officials Authorized to Make Authentic Deed and other Authorities Having referred to in this Act or by another Act is a Notary Public.

Providing Services in the Community then There are two (2) It is important that Attached To Notary, namely in the deed Making Authentic and in giving to the Community Legal counseling. It is not without problems. Notary in carrying out the tasks and many do not interpret His task UUJN and Notary Code. It stretcher caused by Notary Competition is so tight that many notaries who violate UUJN and Notary Code. Similarly, what happens in Banjarnegara.

Based on the description Background the authors are interested in Lifting Problems still yet Answered Regarding Legal counseling conducted by the Notary, therefore the author filed with Title Research "Notary Authority To Provide Legal Counseling Service Based On Notary Law And Notary Code In Banjarnegara".

This study aimed to analyze Authorities Providing Legal counseling Notaries in terms of Act No. 2 of 2014 on Amendment of Act No. 30 of 2004 concerning Notary and Notary Code. To Analyze Barriers and Solutions to Provide Role A Notary in Legal counseling.

\footnotetext{
1 Master of Notary Law Student, Sultan Agung Islamic University Semarang email bondanbushido@gmail.com

2 Students of Master of Law, Faculty Of Law, Universitas Islam Sultan Agung email riskyafsheena@gmail.com

${ }^{3}$ Lecturer in Faculty of Law, Sultan Agung Islamic University

${ }^{4}$ Nyoman Serikat Putra Jaya, 2014, Politik Hukum, Semarang, Universitas Diponegoro Press, p. 117
} 


\section{Research methods}

The method in this paper using the Qualitative Research Methods in Empirical Juridical Approach. Research is Descriptive Analysis specification. Types of data sources, materials Primary Law, Law of materials Secondary and Tertiary Legal materials.

\section{Results And Discussion}

\subsection{Notary Authority in Providing Legal Counseling in Terms of Act No. 2 of 2014 on Amendment of Act No. 30 of 2004 concerning Notary and Notary Code}

In an effort to increase local devotion to the community while also increasing awareness of Community law, Notary also has the Authority set forth in UUJN. The Notary authority in Article 15 of paragraph (1) through (3) UUJN, which can be divided into: 3 ie Notary Public Authority, Special Authority Notaries, Notary authority which will be determined later.

Notary Public authority stipulated in Article 15 (1) UUJN which asserts that one of The Notary authority Deed is Making in General. It can be called as a Notary Public Authority with Restrictions Along:

- Not excluded To the other officials who have been assigned by the Act; namely on other authorized officials in the Making Deed. Like, in Making Birth Certificates, Marriage Deed. Thus, the involvement of other officials in the Making Authentic Deed;

- Regarding the deed that must be made is the Deed of Authentic On All deeds, agreements and Assessment required by the Rule of Law to be made or intended by the Respective; and

- Regarding interest statute subject that interests who should be obvious to a deed was made.

Special Authority Notaries can be found in Article 15 paragraph (2) UUJN Governing Regarding the Special Authority to Take Action Law Notary, such as:

- Endorses Signature and Establishing certainty in the Lower Hand Letter dated by registering it in a Special Book;

- The letters posted in the Hands Down by listing them in a Special Book;

- Make a copy the original of the letters in the Lower Hand Form Copies Loading description as described and illustrated in a letter respective;

- Doing ratification this match between original copy of the letter;

- Providing legal counseling in connection with the preparation of deed; and

- Make deed relating to the land, or make the deed of minutes of the auction.

Notary authority to be determined under Article 15 paragraph (3) UUJN with the authority that will be determined later is a Rule-Based Privileges that another law that would Coming Later (ius constituendum). Notary authority which will be determined later, is the authority which will be determined by legislation. Limitations Regarding what is meant by this legislation can be found in Article 1 paragraph 2 of Act No. 5 of 1986 neighbor Administrative Courts. ${ }^{5}$

\footnotetext{
${ }^{5}$ Habib Adjie, 2008, Hukum Notaris Indonesia, Tafsir Tematik Terhadap UU No. 30 Tahun 2004 tentang Jabatan Notaris, Bandung: PT Refika Aditama, p. 82-83
} 
The authority of a Notary in providing special authority of Legal counseling is provided for in Article 15 paragraph 2 letter e ie Notary Providing Legal counseling in connection with the Preparation of Deed. It is in deed Making Authentic and this is a unity that can not be separated from one another.

Viewed from Article 15 paragraph (2) letter e UUJN on the Authority specifically Notary, based on the results of interviews between the author with several Notary, the authors are able to explain that the authority of Notary in providing Legal counselling to Its clients can be divided into two (2) criteria, ie. Extension making the law followed by Deed and legal counselling without being followed by Creation Deed.

\subsection{Barriers and Solutions to Provide Role A Notary in Legal Counseling}

Legal counseling or description of the provisions of this Act was to assist in the Making Deeds are required and it is an inseparable unity of 1 (one) with each other. The advice must be given by a Notary must be based on a belief in the field of controlled and within the limits of its capabilities. Legal expertise in the field should be in accordance with the legislation in force.

Based on these descriptions author conducted interviews to Nurita Cahtur Wahyuni, $\mathrm{SE}^{6}$ one of the officials of the Bank Tabungan Negara, he was the party that often do contract by the debtor in the Bank Tabungan Negara, he said during a Notary rare to The Bank Legal counselling which in this case is a notary client itself. He also said the Notary sometimes come to the Office of the Bank Tabungan Negara is not coming to the Notary Office.

In the Notary Code also regulates the matters that must be obeyed by a Notary in carrying out His post and also outside run His post. In Article 3 of Notary Code of 2005, the results of the Extraordinary Congress of Notaries Association of Indonesia, Bandung, January 27, 2005 arranged on Liability Notary in carrying out His position must be obeyed and implemented and in Article 4 of Notary Code of 2005, the results of the Extraordinary Congress of Notaries Association of Indonesia, Bandung, January 27, 2005 regulate the prohibition or something that should not be done by a Notary.

In case this is not in accordance with Article 3 point 15 Notary Code of 2005, the results of the Extraordinary Congress of Notaries Association of Indonesia, Bandung, January 27, 2005 which reads: "Running His post in the office, except for certain reasons". If it is associated with the state courts overlooking the neighbour Notary Bank is not coming to the Notary Office. Obviously Notary itself does not carry obligation by not seeing Notary Code.

Based on the exposure of these events back Writer Interview Notary Ahmad Priyo Susetyo, SH, M.Kn. ${ }^{7}$ He said about Facing and Dealing in writing in the deed. It is very common place in the notary in Banjarnegara and the surrounding area. This is because the number of notaries who do not understand their obligation to keep the Notary Public and Notary Code due to a very tight competition Notary and Notary vying to get the Client for its own sake so that Notary Public Notary Code neglect.

According to Abdulkadir Muhammad there are four (4) The fundamental reason Professionals, including Notary, ignoring the Code. These reasons include: Influence of Personality Kinship, Effect Position; Influence of Consumerism; and Because Weak

\footnotetext{
${ }^{6}$ Nurita Cahtur Wahyuni, SE, The Consumer Credit Savings Bank in Banjarnegara, from the interview dated August 31, 2019

7 Ahmad Priyo Susetyo, SH, M.Kn. Notary and PPAT in Banjarnegara district, the results of Interview dated 1 September 2019
} 
Faith. ${ }^{8}$ While I Gede $A B$ Wiranata an inventory of the eight factors influencing the decline of morality which includes the Legal Profession: Abuses Profession, Profession into Business Activity, Lack of Awareness and Social Care, continuation Justice system, Effect Position, Lifestyle Consumerism, Faith and Influence Factors Kinship properties. ${ }^{9}$ If it is associated with barriers to a Notary in running the Legal counseling actually Notary hampered by what the Notary itself by not running obligation as a Notary and by not interpret the meaning of Legal counseling which is set up under Article 15 e of UUJN and Notary Code.

\subsubsection{Barriers Notaries in Conducting Legal Counseling}

Here are things that become barriers Notaries for Notary deed itself:

- Influence of Personality Kinship

One characteristic of Kinship is giving the same treatment and respect to the family members and are considered fair. Treat against another person is not friendly. This affects the Legal Professional Conduct related to the Code of Professional Ethics, which should give the same treatment to the Client. A Professional Notary should distinguish between the issue of Family and Professional Issues. Kinship relations may be removed while in office but remains Kinship ties fostered outside the office;

- Effect of Position

Position influence is also often a factor that led to the Notary apply without mengidahkan Professional Code of Conduct. Acting State Notary Public who serve should treat all people in the same notch. However, due to the influence of Position inherent in a person sometimes Notary act against a client privileged compared with other Clients. Perhaps it is human, but indirectly has made the difference between one human being with another human being. This treatment is a treatment that is not fair and therefore has violated the Notary Public as a Professional Ethics;

- influence of consumerism

Materialistic-paced life can influence the actions of a Negative Notary. Consumerism demands that are part of lifeMaterialistic may come from themselves or family. A Notary when it was seized by the nature of the Notaries Consumer Materialistic and they often take steps that violate the Code of Conduct to meet the satisfaction of her life. Profession regarded as the fields to earn money alone and ignore the service functions inherent in a profession. May be mentioned here merely as an example the number of notaries who do pick up the ball to the Client in order to obtain a maximum Clientsnumber or suggest said every agreement, which in essence is not necessarily using the Notary Deed for the sake of his best-practices that they do;

- Being Profession Business Activity

A man who devoted himself to such a Noble Profession Notaries must understand that different professions with Business Activity. Economic law can not be applied in a Noble Profession. Business focus On Its main objective which is to make a profit, while the ideals of a profession based on a spirit of willingness to provide service to the community. In a business activity necessitated Quantitative value while the profession is sought is not the value but the value of Qualitative. PES in the world of professionalism is not a major thing. There are two (2) principles that influence the PES system.

\footnotetext{
${ }^{8}$ Abdulkadir Muhammad, 2001, Etika Profesi Hukum, Bandung: Citra Aditya Bakti, p. 82-85

${ }^{9}$ I Gede A.B. Wiranata, 2005, Dasar-Dasar Etika dan Moralitas (Pengantar Kajian Etika Profesi Hukum), Bandung:PT Citra Aditya Bakti, p. 261
} 
First, the principle serves within the wages received. This principle takes place or held when raised above profession basing their remuneration real profit or material benefit from services performed for members of the public. This principle allows for various forms of Fraud or Abuse serious. Such a system allows people a chance to use her ability selfishly, even untrue, against one another.

Second, is serving in accordance with the principle of inquiry. This principle can be found in self-professions basing their remuneration for their time, energy and expertise or specialty, as he felt as things that are necessary to be provided. In general, the second principle is considered more Sense, and the possibility of Fraud or Abuse of Position will be small; ${ }^{10}$ and

- Due to Weak Faith

One of the requirements to become a Professional it is Faith to God Almighty, that execute commands and avoid his prohibitions. Faith is the basis of human morality. If humans strengthen the faith with Faith then be embedded within the brake Moral Values to behave badly. With Faith people more aware that good will be rewarded with good, on the contrary vices will be rewarded with evil. Indeed, God is the Most Just. With Faith to God Almighty, professionals have the Moral strong fortress, not easily tempted and tempted by the variety of forms of matter in the vicinity. With strong faith needs will be met in a reasonable and that is happiness.

Thus, according to the opinion writer with a condition that occurs in Banjarnegara on the Authority Notaries in doing Legal counseling has not been done up by Notary in Banjarnegara. Notary in Banjarnegara only do all the Legal counseling in the Making Deed to the notary in Banjarnegara client but rarely do Legal counseling which was not followed by Manufacture Deed.

\subsubsection{Solutions For Solving Notary Obstacles in Conducting Legal Counseling}

Supposedly if a notary in Banjarnegara do Legal counseling are not followed Making Deed is its own solutions to the Notary. These include namely:

- Notaries will have a lot of experience socializing with the community so that notary can recognize many characters in the community where the notary did position notch;

- Notaries will be trusted by the community about their knowledge so that it will be well-known notary in the notary public and Benefits for the widely used on Region Notaries in doing His post; and

- Creation of public awareness in the Deed will be higher for People understand the importance of Creation Deed and the Rights and Duties with the Authentic Deeds.

With the Education Law given by the Notary, it is expected the penghadap Requiring assistance is becoming Understand and understand the decisions that best was going to do as well as before the Notary make Deed desired by His client, a notary must first provide a description of the state of law that is actually to clients, their rights and obligations of each, so that the client understands the real situation. It stretcher is a Notary Solutions that violations in UUJN and Notary Code will be reduced due to the Notary Competition is so tight.

\section{Closing}

\subsection{Conclusion}

${ }^{10}$ E. Sumaryono, 1995, Etika Profesi Hukum, Yogyakarta: Kanisius, p. 43-44 
- Notary authority in carrying out its duties divided into 3 (three), namely: public authority: the authority of the notaries in making deed history; special authority is set regarding special authority to take action law notary certain one of them on the authority notaries in conducting legal counseling; notary authority will determined later that powers the other by the rule of law coming later (ius constituendum). Notary authority in providing Legal counseling to Its clients can be divided into two (2) criteria, ie Legal counseling followed by Creation Deed and Legal counseling without being followed by Creation Deed.

- Constraints notaries in doing notaries legal counseling is in itself not aware of the importance of legal counseling. Here are the things that become barriers notary for his own actions, namely: influence of personality kinship; effect of position; influence of consumerism; professions business activity; and because weak faith.

- Meanwhile, a solution to resolve the barriers notaries in doing legal counseling is to do legal counseling which is not followed by creation deed, so that if a notary do legal counseling will acquire solutions and benefits included: a notary will have a lot of experience socialize with community so notaries can recognize lots of character in the community where the status of notaries do his post; notaries will be trusted by the community about their knowledge so that the notary will be famous people and profits for the notary public notary is widely used in the region in doing his post; and public awareness in the making deed will be higher for people understand the importance of making deeds and the rights and duties with the authentic deeds.

\subsection{Suggestion}

- So that more optimizing notary legal counseling to not only do the deed making legal counseling in the making deeds followed but rather an extension optimizing law without being followed creation deed.

- Notary should better understand the meaning of what is contained in Article 15 (2) e of the Notaries do Legal counseling in carrying out the task and does not violate UUJN on position and Notary Code.

- With Giving Legal counseling Community where Notary Territory is located, Community closer emotional relationship between the Community and Notary, because in this way the Notary Public and will equally benefit the community obtain information about matters related to Civil Law. Notary gain advantage by giving the same socialization notary also advertises themselves but not break.

\section{References}

\section{Books}

[1] Abdulkadir Muhammad, 2001, Etika Profesi Hukum, Bandung: Citra Aditya Bakti.

[2] E. Sumaryono, 1995, Etika Profesi Hukum, Yogyakarta: Kanisius.

[3] Habib Adjie, 2008, Hukum Notaris Indonesia, Tafsir Tematik Terhadap UU No. 30 Tahun 2004 tentang Jabatan Notaris, Bandung: PT Refika Aditama.

[4] I Gede A.B. Wiranata, 2005, Dasar-Dasar Etika dan Moralitas (Pengantar Kajian Etika Profesi Hukum), Bandung: PT Citra Aditya Bakti.

[5] Nyoman Serikat Putra Jaya, 2014, Politik Hukum, Semarang, Universitas Diponegoro Press.

\section{Interview}

[1] Ahmad Priyo Susetyo, SH, M.Kn. Notary and PPAT in Banjarnegara district, the results of Interview dated 1 September 2019 
Volume 6 Issue 3, September 2019

[2] Nurita Cahtur Wahyuni, SE, Bank Tabungan Negara Consumer Credit in Banjarnegara, from the interview dated August 31, 2019 